\title{
Revival of the genus Lentzea and proposal for Lechevalieria gen. nov.
}

\author{
1 Microbial Properties \\ Research Unit, National \\ Center for Agricultural \\ Utilization Research, \\ 1815 N. University Street, \\ Agricultural Research \\ Service, US Department \\ of Agriculture, Peoria, \\ IL 61604, USA \\ 2 Institute for Fermentation \\ Osaka, Osaka, Japan \\ 3 DSMZ-Germany Collection \\ of Microorganisms and Cell \\ Cultures, Braunschweig, \\ Germany
}

\author{
D. P. Labeda, ${ }^{1}$ K. Hatano, ${ }^{2}$ R. M. Kroppenstedt ${ }^{3}$ and T. Tamura ${ }^{2}$ \\ Author for correspondence: D. P. Labeda. Tel: +1 309681 6397. Fax: +1 3096816672. \\ e-mail: labedadp@mail.ncaur.usda.gov
}

The genus Saccharothrix is phylogenetically heterogeneous on the basis of analysis of almost complete $16 \mathrm{~S}$ rDNA sequences. An evaluation of chemotaxonomic, morphological and physiological properties in the light of the molecular phylogeny data revealed that several species are misclassified. Saccharothrix aerocolonigenes NRRL B-3298 ${ }^{\top}$ and Saccharothrix flava NRRL B$16131^{\top}$ constitute a lineage distinct from Saccharothrix and separate from Lentzea. The genus Lechevalieria gen. nov. is proposed for these species. Lechevalieria aerocolonigenes comb. nov. is the type species and S. flava is transferred as Lechevalieria flava comb. nov. Although Lentzea albidocapillata, the type species of the genus Lentzea, was transferred recently to the genus Saccharothrix, the revival of Lentzea is clearly supported by molecular phylogenetic and chemotaxonomic data. The description of the revived genus is emended to include galactose, mannose and traces of ribose as diagnostic whole-cell sugars and MK-9 $\left(\mathrm{H}_{4}\right)$ as the principal menaquinone and elimination of tuberculostearic acid as a diagnostic component in the fatty acid profile. Saccharothrix waywayandensis NRRL B-16159', S. aerocolonigenes NRRL B16137 and 'Asiosporangium albidum' IFO 16102 are members of the amended genus Lentzea on the basis of phylogenetic and chemotaxonomic properties. $S$. waywayandensis is transferred to Lentzea as Lentzea waywayandensis comb. nov., while the new species Lentzea californiensis sp. nov. and Lentzea albida sp. nov. are described for S. aerocolonigenes NRRL B-16137 and 'A. albidum' IFO 16102, respectively. Nucleotide signatures in the 165 rDNA sequences are defined that are diagnostic for the genera Lechevalieria, Lentzea and Saccharothrix.

Keywords: Pseudonocardineae, Actinosynnemataceae, Saccharothrix

\section{INTRODUCTION}

A phylogenetic analysis of species of the genus Saccharothrix and allied taxa within the family Actinosynnemataceae, based on partial 16S rDNA sequences (Labeda \& Kroppenstedt, 2000), demonstrated that Saccharothrix is phylogenetically heterogeneous and that several of the described species are misclassified. It was noted that Saccharothrix waywayandensis NRRL B- $165159^{\mathrm{T}}$ is more closely related phylogenetically to Lentzea albidocapillata than to Saccharothrix sensu stricto and that Saccharothrix aerocolonigenes NRRL

The GenBank accession number for the almost complete sequence of the 16S rDNA gene of Saccharothrix aerocolonigenes NRRL B-16137 is AF174435.
B-3298 ${ }^{\mathrm{T}}$ and Saccharothrix flava NRRL B-16131 ${ }^{\mathrm{T}}$ form a lineage distinct from Saccharothrix and separate from Lentzea. The previous study of Tamura \& Hatano (1998) also demonstrated that 'Asiosporangium albidum' IFO 16102 is phylogenetically related to Saccharothrix and Lentzea. A recent proposal (Lee et al., 2000) suggested that Lentzea albidocapillata, the type species of the genus Lentzea, be transferred into the genus Saccharothrix, thus effectively abolishing this genus under the rules of the Bacteriological Code of Nomenclature (Lapage et al., 1992), but the phylogenetic and chemotaxonomic data in the present study do not support this proposal. An evaluation of the chemotaxonomic, morphological and physiological properties of these actinomycetes was undertaken to clarify their taxonomic position. 


\section{METHODS}

Strains, cultivation and maintenance. The strains evaluated in the present study are listed in Fig. 1. Primary storage of strains was as lyophilized ampoules of mycelial and spore suspensions in sterile beef serum held at $4^{\circ} \mathrm{C}$. Working stock cultures were maintained on slants of ATCC medium no. 172 (Cote et al., 1984) and stored at $4{ }^{\circ} \mathrm{C}$ until needed. Biomass for extraction of DNA was grown as $7 \mathrm{~d}$ streak cultures on ATCC medium no. 172 agar plates.

Chemotaxonomy. Chemotaxonomic analysis of strains for menaquinones, fatty acids and whole-cell sugars was performed using methods described previously (Grund \& Kroppenstedt, 1989).

Physiological tests. Physiological tests, including those for the production of acid from carbohydrates, the utilization of organic acids and the hydrolysis and decomposition of adenine, guanine, hypoxanthine, tyrosine, xanthine, casein, aesculin, urea and hippurate, were evaluated by using the media of Gordon et al. (1974). Allantoin hydrolysis was evaluated in the basal medium suggested by Gordon et al. (1974) for aesculin hydrolysis. Phosphatase activity was evaluated by using the method of Kurup \& Schmitt (1973). The temperature range for growth was determined on slants of ATCC medium no. 172 agar (Cote et al., 1984).

DNA isolation, 16S rDNA gene amplification and sequencing. Genomic DNA was isolated, purified and sequenced using procedures described previously (Labeda \& Kroppenstedt, 2000).

Phylogenetic analysis. The $16 \mathrm{~S}$ rDNA sequences obtained in this study were aligned manually with actinomycete reference sequences obtained from the Ribosomal Database Project (Maidak et al., 1994) and GenBank in the ARB software environment for sequence data that was developed by Wolfgang Ludwig and Oliver Strunk (Lehrstuhl für Mikrobiologie, University of Munich, Germany). The program PHYLO_WIN (Galtier et al., 1996) was used to calculate evolutionary distances (using the method of Kimura, 1980) and linkages (using the neighbour-joining method of Saitou \& Nei, 1987) and to perform maximumparsimony and maximum-likelihood analyses. The topographies of the trees resulting from neighbour-joining and maximum-parsimony analyses were evaluated by bootstrap analysis of the data (with 500 resamplings).

\section{RESULTS AND DISCUSSION}

The neighbour-joining dendrogram for the family Actinosynnemataceae, resulting from phylogenetic analysis of $16 \mathrm{~S}$ rDNA sequences, is shown in Fig. 1; it can be clearly observed that the genus Saccharothrix sensu lato exhibits phylogenetic heterogeneity upon analysis based on almost complete sequences of $16 \mathrm{~S}$ rDNA. Similar tree topographies resulted from analy-

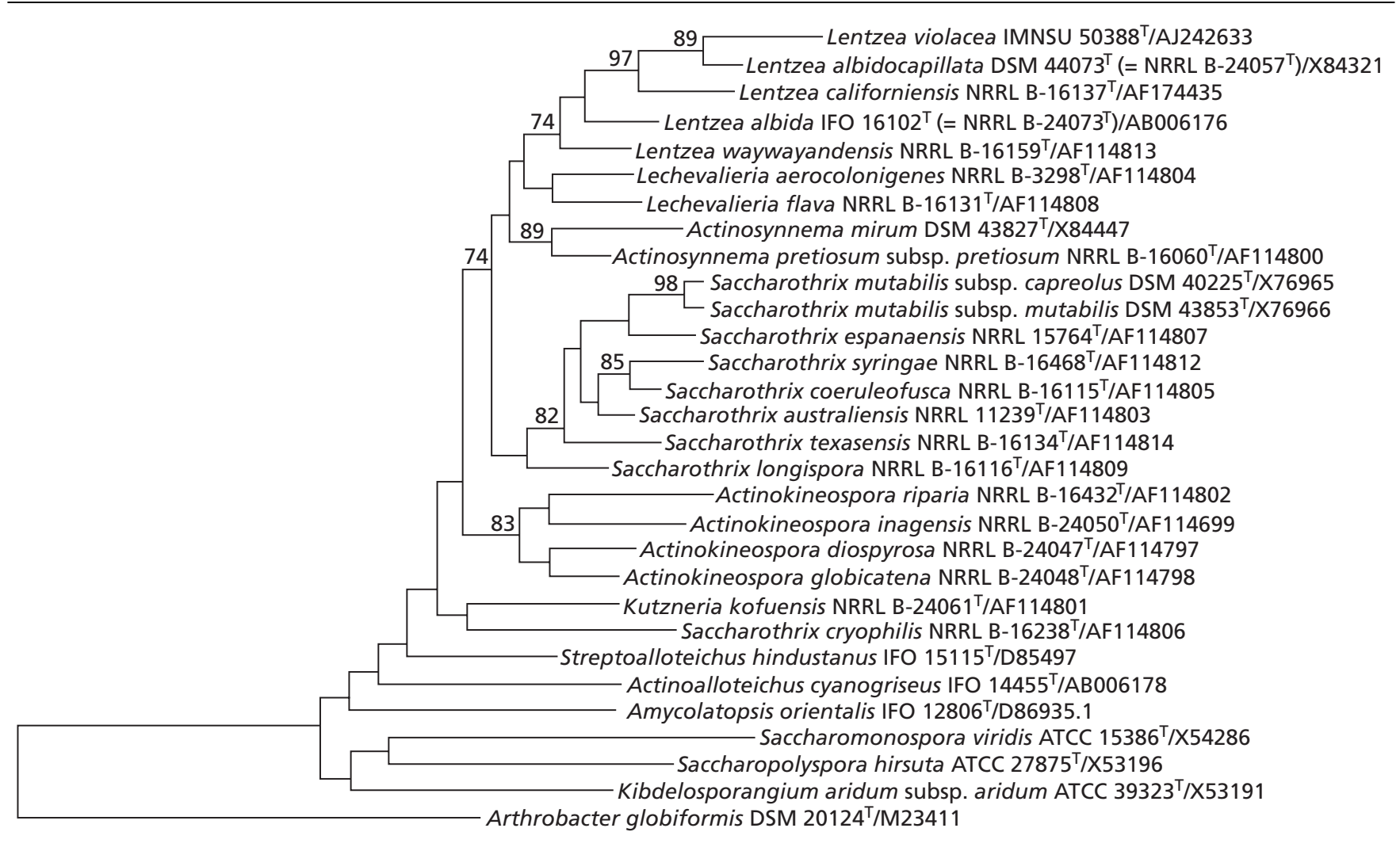

$0 \cdot 10$

Fig. 1. Phylogenetic dendrogram reconstructed from evolutionary distances (Kimura, 1980) by the neighbour-joining method (Saitou \& Nei, 1987), indicating the positions of species of the genera within the family Actinosynnemataceae. Bar, $0 \cdot 1$ nucleotide substitutions per site. 
Revival of Lentzea, and Lechevalieria gen. nov.

Lechevalieria aerocolonigenes NRRL B-3298 ${ }^{\mathrm{T}}$

Lechevalieria flava NRRL B-16131 ${ }^{\mathrm{T}}$

Lentzea albida $\mathrm{IFO} 16102^{\mathrm{T}}$

Lentzea albidocapillata DSM $44073^{\mathrm{T}}$

Lentzea californiensis NRRL B-16137 ${ }^{\mathrm{T}}$

Lentzea violacea IMSNU $50388^{\mathrm{T}}$

Lentzea waywayandensis NRRL B-16159 ${ }^{\mathrm{T}}$

Actinosynnema mirum DSM $43827^{\mathrm{T}}$

Actinosynnema pretiosum subsp. pretiosum NRRL B-16060 ${ }^{\mathrm{T}}$

Saccharothrix australiensis NRRL $11239^{\mathrm{T}}$

Saccharothrix coeruleofusca NRRL B-16115 ${ }^{\mathrm{T}}$

Saccharothrix espanaensis NRRL $15764^{\mathrm{T}}$

Saccharothrix longispora NRRL B-16116 ${ }^{\mathrm{T}}$

Saccharothrix mutabilis subsp. capreolus DSM $40225^{\mathrm{T}}$

Saccharothrix mutabilis subsp. mutabilis DSM $43853^{\mathrm{T}}$

Saccharothrix syringae NRRL B-16468 ${ }^{\mathrm{T}}$

Saccharothrix texasensis NRRL B-16134 ${ }^{\mathrm{T}}$

\begin{tabular}{|c|c|c|c|c|}
\hline$i^{601}$ & ${ }_{1}^{611}$ & 621 & 841 & 1001 \\
\hline AAACTTGGGG & СТTAАCCCCG & AGCCTGCGGT & ACGTTCTCCG & GAAACCGGTA \\
\hline$\cdots$ & ........... & …… & $\ldots \ldots \ldots \ldots$ & ........ \\
\hline$\ldots \ldots \ldots$ & …… & ..т..... & ...сс...т. & ......... \\
\hline$\cdots$ & $\ldots \ldots$ та & $\ldots$...... & ..сс...т. & ....G.тC.. \\
\hline$\cdots$ & …... & ..т...с. & ..сс...т. & ......... \\
\hline$\ldots \ldots \ldots$ & …… & $\ldots$ т..... & ..сс..тт. & ....я.тс. \\
\hline ....... & …T.A & ...т...... & ...сс...т. & ......т.т. \\
\hline ....... & $\ldots \ldots \ldots \ldots$ & n.m. & ...c..... & .......... \\
\hline$\cdots \cdots$ & $\ldots \ldots \ldots \ldots$ & ..т..... & $\ldots \ldots c \ldots$ & „......... \\
\hline .....CAC. & .....GTG. & ........... & ....c..... & ...... тсс. \\
\hline .....CAC. & ......GTG. & n.m. & ...с..... & …т.т.с. \\
\hline ......CAC. & ......GTG. & n.m. & ...c...... & …т.т.с. \\
\hline .....CAC. & ......GTG. & .......... & ....c..... & .......... \\
\hline ....CAC. & ...N..GTG. & n.m. & ...c..... & ….. тсс. \\
\hline .... CAC. & .N...GTG. & $\cdots \cdots \cdots$ & ...c..... & ...... тсс. \\
\hline ... CAC. & ......GTG. & $\ldots \ldots \ldots$ & $\ldots$....... & …‥с.с. \\
\hline . . CAC. & ......GTG. & …..... & $\ldots$.с.... & …т. \\
\hline
\end{tabular}

Fig. 2. Signatures in the $16 \mathrm{~S}$ rDNA sequence for the genera Lechevalieria, Lentzea and Saccharothrix.

ses using the maximum-parsimony and maximumlikelihood algorithms (trees not shown). The phylogenetic position of Saccharothrix cryophilis NRRL B$16238^{\mathrm{T}}$ indicates that this species does not belong in the genus Saccharothrix and that it probably does not belong within the family Actinosynnemataceae, but this will be the subject of another detailed paper. $S$. aerocolonigenes NRRL B-16137, Saccharothrix violacea IMNSU $50388^{\mathrm{T}}$, S. waywayandensis NRRL B-16159 ${ }^{\mathrm{T}}$ and 'A. albidum' IFO 16102 form a lineage that contains Lentzea albidocapillata DSM $44073^{\mathrm{T}}$ (97.8\% mean intrageneric nucleotide similarity), the type species of the genus, which is also clearly separated phylogenetically from Saccharothrix sensu stricto, with a mean nucleotide similarity of $95.8 \%$ between all species of both genera. These strains also share similar chemotaxonomic characteristics, and it is proposed that they be transferred to the revived and emended genus Lentzea.

The type strains of $S$. aerocolonigenes and S. flava, respectively NRRL B-3298 ${ }^{\mathrm{T}}$ and NRRL B-16131 ${ }^{\mathrm{T}}$, consistently formed a monophyletic lineage distinct from Saccharothrix (mean nucleotide similarity of $96.8 \%$ to species of this genus) and intermediate between Lentzea (mean nucleotide similarity of $96.7 \%$ to species of this genus) and Actinosynnema (mean nucleotide similarity of $97 \cdot 3 \%$ to species of this genus) for all of the algorithms tested. The phylogenetic validity of the genera Actinosynnema, Lentzea and Saccharothrix was consistently well supported statistically by all algorithms used; the $S$. aerocolonigenes and $S$. flava lineage was consistently found between Actinosynnema and Lentzea, regardless of which algorithm was used. An examination of the aligned sequences for the 16S rDNA gene (Fig. 2) revealed that diagnostic nucleotide signatures can be used to differentiate the $S$. aerocolonigenes $-S$. flava lineage from Lentzea and Actinosynnema and that they can also be used to differentiate them from the other genera of the Actinosynnemataceae. Although S. aerocolonigenes and $S$. flava appear to be phylogenetically close to the genus Actinosynnema, neither has been observed to produce coremia with chains of motile spores (this feature being characteristic of this genus). It is therefore proposed that the $S$. aerocolonigenes $-S$. flava lineage represents a new genus, to be called Lechevalieria gen. nov.

Analysis of the chemotaxonomic characteristics of Lentzea albidocapillata DSM $44073^{\mathrm{T}}$ in the present study revealed the presence of galactose, mannose and ribose as diagnostic sugars and menaquinone MK$9\left(\mathrm{H}_{4}\right)$ as the predominant menaquinone and the absence of any significant amount of 10-methyl C18:0 fatty acids (tuberculostearic acid). This is largely in agreement with the observations of Lee et al. (2000) regarding this strain. Galactose and mannose were found as diagnostic sugars in whole-cell hydrolysates of all strains examined, but 'A albidum' IFO 16102 and $S$. aerocolonigenes NRRL B-16137 contained ribose, while $S$. waywayandensis NRRL B- $16159^{\mathrm{T}}, S$. aerocolonigenes NRRL B-3298 ${ }^{\mathrm{T}}$ and $S$. flava NRRL B$16131^{\mathrm{T}}$ did not. Whilst the genera Lechevalieria and Lentzea (including 'A. albidum', S. aerocolonigenes NRRL B-16137 and S. waywayandensis NRRL B$16159^{\mathrm{T}}$ ) share many diagnostic chemotaxonomic characteristics with Saccharothrix, they can be distinguished from this genus by the lack of hydroxysubstituted fatty acids in the phosphatidyl ethanolamine component of their phospholipids (Table 1). Saccharothrix and Lechevalieria strains tend to contain varying amounts of rhamnose in whole-cell hydrolysates, whereas Lentzea strains were observed to lack (or contain only trace amounts of) rhamnose, and might also contain ribose.

All species of Lentzea produce branching substrate mycelium, and the aerial mycelium fragments into rodshaped elements, although Lentzea waywayandensis 
Table 1. Chemotaxonomic characteristics of Lechevalieria compared with other genera of the family Actinosynnemataceae

All of the genera have meso-diaminopimelic acid as the cell wall diamino acid, are of cell wall chemotype III and contain straightchain, mono-unsaturated, iso and anteiso fatty acids. Abbreviations: DPG, diphosphatidyl glycerol; PE, phosphatidyl ethanolamine; PG, phosphatidyl glycerol; PI, phosphatidyl inositol; PIMs, phosphatidyl inositol mannosides; PME, phosphatidyl methylethanolamine.

\begin{tabular}{|c|c|c|c|c|c|c|}
\hline Characteristic & Actinokineospora & Actinosynnema & Asiosporangium & Lechevalieria & Lentzea & Saccharothrix \\
\hline Whole-cell sugar pattern & $\begin{array}{c}\text { Galactose, mannose, } \\
\text { rhamnose }\end{array}$ & Galactose, mannose & $\begin{array}{c}\text { Galactose, mannose, } \\
\text { ribose }\end{array}$ & $\begin{array}{l}\text { Galactose, mannose, } \\
\text { rhamnose }\end{array}$ & $\begin{array}{c}\text { Galactose, mannose, } \\
\text { ribose }\end{array}$ & $\begin{array}{c}\text { Galactose, rhamnose, } \\
\text { mannose (trace) }\end{array}$ \\
\hline Phospholipid type & PII & PII & PII & PII & PII & PII, PIV \\
\hline Phospholipids & PE, OH-PE & PE, OH-PE, PI, PIMs, DPG & $\mathrm{PE}$ & $\mathrm{PE}$ & PE, DPG, PG, PI & $\begin{array}{c}\text { PE, OH-PE, PI, PIMs, } \\
\text { DPG, PG }\end{array}$ \\
\hline Predominant menaquinones & MK-9 $\left(\mathrm{H}_{4}\right)$ & MK-9( $\left.\mathrm{H}_{4}\right)$, MK-9( $\left.\mathrm{H}_{6}\right)$ & MK-9 $\left(\mathrm{H}_{4}\right)$ & MK-9 $\left(\mathrm{H}_{4}\right)$ & MK-9 $\left(\mathrm{H}_{4}\right)$ & MK-10( $\left(\mathrm{H}_{4}\right)$, MK-9( $\left.\mathrm{H}_{4}\right)$ \\
\hline
\end{tabular}

Table 2. Differential physiological properties of Lentzea species

w, Weak positive reaction. Data for Lentzea violacea were taken from Lee et al. (2000).

\begin{tabular}{|c|c|c|c|c|c|}
\hline Property & $\begin{array}{c}\text { Lentzea } \\
\text { albidocapillata } \\
\text { NRRL B-24057 }\end{array}$ & $\begin{array}{c}\text { Lentzea albida } \\
\text { NRRL B-24073 }\end{array}$ & $\begin{array}{c}\text { Lentzea } \\
\text { californiensis } \\
\text { NRRL B-16137 }\end{array}$ & $\begin{array}{l}\text { Lentzea violacea } \\
\text { IMSNU } 50388^{\mathrm{T}}\end{array}$ & $\begin{array}{c}\text { Lentzea } \\
\text { waywayandensis } \\
\text { NRRL B-16159 }\end{array}$ \\
\hline Hydrolysis of urea & w & $\mathrm{w}$ & + & + & + \\
\hline Nitrate reductase production & - & - & + & - & + \\
\hline \multicolumn{6}{|l|}{ Assimilation of: } \\
\hline Acetate & - & + & + & + & + \\
\hline Citrate & - & + & + & - & + \\
\hline Lactate & - & - & - & + & + \\
\hline Malate & + & + & + & - & + \\
\hline \multicolumn{6}{|l|}{ Production of acid from: } \\
\hline Adonitol & + & + & - & - & + \\
\hline Cellobiose & + & + & + & - & + \\
\hline Inositol & + & + & + & - & + \\
\hline Maltose & + & + & + & - & + \\
\hline Mannitol & + & + & + & - & + \\
\hline Raffinose & w & - & + & + & + \\
\hline Rhamnose & + & + & + & - & + \\
\hline Sucrose & + & + & + & - & + \\
\hline Trehalose & + & + & + & - & + \\
\hline Xylose & + & + & + & - & + \\
\hline \multicolumn{6}{|l|}{ Growth at: } \\
\hline $10{ }^{\circ} \mathrm{C}$ & + & - & + & + & + \\
\hline $37^{\circ} \mathrm{C}$ & + & + & + & + & $\mathrm{W}$ \\
\hline $42{ }^{\circ} \mathrm{C}$ & - & + & - & - & - \\
\hline $45^{\circ} \mathrm{C}$ & - & + & - & - & - \\
\hline
\end{tabular}

NRRL B-16159 ${ }^{\mathrm{T}}$ produces only relatively sparse aerial mycelium in comparison with the other Lentzea species. Both species of Lechevalieria produce very sparse aerial mycelium on agar media and have not been observed to produce sporangia, coremia or motile spores, which differentiates them from Actinokineospora and Actinosynnema.

It is proposed that the formal description of the revived genus Lentzea be emended to include updated chemotaxonomic data from both the present study and that of Lee et al. (2000). On the basis of the data presented,
S. violacea is transferred as Lentzea violacea comb. nov., $S$. waywayandensis is transferred as Lentzea waywayandensis comb. nov. and ' $A$. albidum' IFO 16102 is validly described as Lentzea albida sp. nov. Because it is proposed that the type strain of $S$. aerocolonigenes be transferred to the new genus Lechevalieria and as strain NRRL B-16137 is a member of the genus Lentzea, it is described as the new species Lentzea californiensis sp. nov. The physiological properties that differentiate these species are shown in Table 2 and the formal descriptions are given below. 
Table 3. Differential physiological properties of Lechevalieria species

$\mathrm{w}$, Weak positive reaction.

\begin{tabular}{|lcc|}
\hline Property & $\begin{array}{c}\text { Lechevalieria } \\
\text { aerocolonigenes } \\
\text { NRRL B-3298 }\end{array}$ & $\begin{array}{c}\text { Lechevalieria } \\
\text { flava } \text { NRRL } \\
\text { B-16131 }^{\text {N }}\end{array}$ \\
\hline Growth in the presence of: & & \\
$4 \% \mathrm{NaCl}$ & + & - \\
$5 \% \mathrm{NaCl}$ & + & - \\
Utilization of lactate & + & - \\
Production of acid from: & & - \\
Adonitol & + & + \\
Salicin & + & - \\
Growth at $45^{\circ} \mathrm{C}$ & - & \\
\hline
\end{tabular}

The physiological properties that differentiate the Lechevalieria species can be seen in Table 3 and the formal descriptions of the genus Lechevalieria and the species Lechevalieria aerocolonigenes and Lechevalieria flava are also given below.

\section{Emended description of Lentzea nom. rev., emend.}

The formal description of Yassin et al. (1995) is emended to reflect the following changes in the chemotaxonomic characteristics. The diagnostic whole-cell sugars include galactose and mannose and might also include ribose. The major menaquinone is MK-9 $\left(\mathrm{H}_{4}\right)$. Tuberculostearic acid is found only in trace quantities, if at all, in fatty acid profiles. The sequence of the $16 \mathrm{~S}$ rRNA gene contains a genusspecific diagnostic nucleotide signature pattern, namely TCCA (617-620) and GCC (843-845).

\section{Description of Lentzea albida sp. nov.}

Lentzea albida (al'bi.da. L. fem. adj. albida whitish, referring to the colour of the aerial mycelium).

Substrate mycelium is a yellowish-orange in colour on most media. Copious white aerial mycelium is produced. Soluble pigments are not produced. Casein, aesculin, hypoxanthine, starch and tyrosine are hydrolysed. No hydrolysis of adenine, allantoin or xanthine. Growth occurs in the presence of 4 and $5 \% \mathrm{NaCl}$. Assimilates acetate, citrate, malate, propionate and succinate. Does not assimilate benzoate, lactate, mucate, oxalate or tartrate. Acid is produced from adonitol, arabinose, cellobiose, dextrin, fructose, galactose, glucose, glycerol, inositol, maltose, mannitol, mannose, melibiose, rhamnose, sucrose, trehalose and xylose. Acid is weakly produced from lactose. No acid is produced from dulcitol, erythritol, methyl $\beta$-xyloside, raffinose or sorbitol. Grows at 37 and $42{ }^{\circ} \mathrm{C}$ but not at $45^{\circ} \mathrm{C}$. Isolated from a soil sample collected in Jianbxi Province, People's Republic of China. The type strain of Lentzea albida is IFO $16102^{\mathrm{T}}(=\mathrm{NRRL}$ B-24073 ${ }^{\mathrm{T}}$.

\section{Description of Lentzea californiensis sp. nov.}

Lentzea californiensis (cal.i.for.ni.en'sis. N.L. gen. n. californiensis of California, referring to the source of this isolate, soil from California).

Substrate mycelium is yellow to orange-brown. White aerial mycelium is produced. Orange, soluble pigments may be produced on Czapek's agar. Casein, aesculin, hypoxanthine, starch and tyrosine are hydrolysed. Does not hydrolyse adenine, allantoin or xanthine. Grows in the presence of $5 \% \mathrm{NaCl}$. Assimilates citrate, malate, propionate and succinate. Does not assimilate acetate, benzoate, lactate, mucate, oxalate or tartrate. Acid is produced from arabinose, cellobiose, dextrin, fructose, galactose, glucose, glycerol, inositol, lactose, maltose, mannitol, mannose, melibiose, raffinose, rhamnose, sucrose, trehalose and xylose; acid is not produced from adonitol, dulcitol, erythritol, methyl $\beta$ xyloside or sorbitol. Grows at $37^{\circ} \mathrm{C}$ but not at $42^{\circ} \mathrm{C}$. Isolated from a soil sample from California. Strain NRRL B-16137 was originally classified as Saccharothrix aerocolonigenes. The type strain of Lentzea californiensis is NRRL B-16137 $7^{\mathrm{T}}\left(=\mathrm{DSM} 43393^{\mathrm{T}}=\right.$ IMRU $550^{\mathrm{T}}$ ).

\section{Description of Lentzea violacea comb. nov.}

Basonym Saccharothrix violacea Lee et al. 2000.

The morphological and physiological properties of this species have been described previously (Lee et al., 2000). The type strain of Lentzea violacea is IMSNU $50388^{\mathrm{T}}$.

\section{Description of Lentzea waywayandensis comb. nov.}

Basonym Saccharothrix waywayandensis Labeda and Lyons 1989.

The morphological and physiological properties of this species have been described previously (Labeda \& Lyons, 1989). The type strain of Lentzea waywayandensis is NRRL B-16159 ${ }^{\mathrm{T}}\left(=\mathrm{DSM} 44232^{\mathrm{T}}=\mathrm{IFO}\right.$ $\left.14970^{\mathrm{T}}\right)$.

\section{Description of Lechevalieria gen. nov.}

Lechevalieria (Le.che.val.i.er'i.a. N.L. fem. n. Lechevalieria of Lechevalier, named after the American microbiologists Hubert and Mary Lechevalier, who contributed substantially to the field of actinomycete biology during their careers at the Waksman Institute of Microbiology).

Branching vegetative mycelium (approx. $0.5 \mu \mathrm{m}$ in diameter) is produced. Very scant aerial mycelium is produced on some media. Gram-positive. Lysozymeresistant. Catalase-positive and aerobic. The cell wall 
is of type III (meso-diaminopimelic acid). The wholecell sugar pattern consists of galactose, mannose and traces of rhamnose. Possesses the type PII phospholipid pattern, with significant quantities of phosphatidyl ethanolamine lacking hydroxylated fatty acids. The predominant menaquinone is $\mathrm{MK}-9\left(\mathrm{H}_{4}\right)$. The fatty acid profile consists of saturated and monounsaturated iso and anteiso fatty acids. Phylogenetically, the genus represents a line of descent in the Actinosynnemataceae adjacent to the genus Saccharothrix and close to the genera Actinosynnema and Lentzea. The sequence of the 16S rRNA gene contains a genus-specific diagnostic nucleotide signature pattern, namely TT (844-845) and GGT (1107-1109). The type species is Lechevalieria aerocolonigenes.

\section{Description of Lechevalieria aerocolonigenes comb. nov.}

Basonym Saccharothrix aerocolonigenes (ex Shinobu and Kawato 1960) Labeda 1986.

The morphological and physiological properties of this species have been described previously (Labeda, 1986). The type strain of Lechevalieria aerocolonigenes is NRRL B-3298 $8^{\mathrm{T}}\left(=\right.$ ATCC $23870^{\mathrm{T}}=$ CCRC $13661^{\mathrm{T}}$ $=\operatorname{DSM} 40034^{\mathrm{T}}=$ IFO $\left.13195^{\mathrm{T}}=\mathrm{JCM} 4150^{\mathrm{T}}\right)$.

\section{Description of Lechevalieria flava comb. nov.}

Basonym Saccharothrix flava (Gauze et al. 1974) Grund and Kroppenstedt 1990.

The morphological and physiological properties of this species have been described previously (Grund \& Kroppenstedt, 1989). The type strain of Lechevalieria flava is NRRL B-16131 $1^{\mathrm{T}}\left(=\right.$ ATCC $29533^{\mathrm{T}}=$ CCRC $13328^{\mathrm{T}}=\mathrm{DSM} 43885^{\mathrm{T}}=\mathrm{IFO} 14521^{\mathrm{T}}=\mathrm{INA} 2171^{\mathrm{T}}$ $=\mathrm{JCM} 3296^{\mathrm{T}}$ ).

\section{ACKNOWLEDGEMENTS}

The able technical assistance of E. N. Hoekstra during the analysis of physiological properties, the isolation and purification of DNA, the PCR amplification of 16S rDNA and the sequence determinations for this study is gratefully acknowledged.

\section{REFERENCES}

Cote, R., Daggett, P.-M., Gantt, M. J., Hay, R., Jong, S.-C. \& Pienta, P. (1984). ATCC Media Handbook. Manassas, VA: American Type Culture Collection.

Galtier, N., Gouy, M. \& Gautier, C. (1996). SEAVIEW and PHYLO_ WIN : two graphic tools for sequence alignment and molecular phylogeny. Comput Appl Biosci 12, 543-548.

Gordon, R. E., Barnett, D. A., Handerhan, J. E. \& Pang, C. H. (1974). Nocardia coeliaca, Nocardia autotrophica, and the nocardin strain. Int $J$ Syst Bacteriol 24, 54-63.

Grund, E. \& Kroppenstedt, R. M. (1989). Transfer of five Nocardiopsis species to the genus Saccharothrix Labeda et al. 1984. Syst Appl Microbiol 12, 267-274.

Kimura, M. (1980). A simple method for estimating evolutionary rates of base substitutions through comparative studies of nucleotide sequences. J Mol Evol 16, 111-120.

Kurup, P. V. \& Schmitt, J. A. (1973). Numerical taxonomy of Nocardia. Can J Microbiol 19, 1035-1048.

Labeda, D. P. (1986). Transfer of "Nocardia aerocolonigenes" (Shinobu and Kawato 1960) Pridham 1970 into the genus Saccharothrix Labeda, Testa, Lechevalier, and Lechevalier 1984 as Saccharothrix aerocolonigenes sp. nov. Int J Syst Bacteriol 36, 109-110.

Labeda, D. P. \& Kroppenstedt, R. M. (2000). Phylogenetic analysis of Saccharothrix and related taxa: proposal for Actinosynnemataceae fam. nov. Int J Syst Evol Microbiol 50, 331-336.

Labeda, D. P. \& Lyons, A. J. (1989). Saccharothrix texasensis sp. nov. and Saccharothrix waywayandensis sp. nov. Int J Syst Bacteriol 39, 355-358.

Lapage, S. P., Sneath, P. H. A., Lessel, E. F., Skerman, V. B. D., Seeliger, H. P. R. \& Clark, W. A. (editors). (1992). International Code of Nomenclature of Bacteria (1990 Revision). Bacteriological Code. Washington, DC: American Society for Microbiology.

Lee, S. D., Kim, E. S., Roe, J.-H., Kim, J., Kang, S.-O. \& Hah, Y. C. (2000). Saccharothrix violacea sp. nov., isolated from a gold mine cave, and Saccharothrix albidocapillata comb. nov. Int $J$ Syst Evol Microbiol 50, 1315-1323.

Maidak, B. L., Larsen, N., McCaughey, M. J., Overbeek, R., Olsen, G. J., Fogel, K., Blandy, J. \& Woese, C. R. (1994). The Ribosomal Database Project. Nucleic Acids Res 22, 3485-3487.

Saitou, N. \& Nei, M. (1987). The neighbor-joining method: a new method for reconstructing phylogenetic trees. Mol Biol Evol 4, 406-425.

Tamura, T. \& Hatano, K. (1998). Phylogenetic analyses on the strains belonging to invalidated genera of the order Actinomycetales. Actinomycetologica 12, 15-28.

Yassin, A. F., Rainey, F. A., Brzezinka, H., Jahnke, K.-D., Weissbrodt, H., Budzikiewicz, H., Stackebrandt, E. \& Schaal, K. P. (1995). Lentzea gen. nov., a new genus of the order Actinomycetales. Int J Syst Bacteriol 45, 357-363. 